\title{
Performance of Six Cenchrus and Four Panicum Forage Grasses Under Cutting Management in the Lajas Valley, Puerto Rico'
}

\author{
J. Vélez-Santiago, A. Sotomayor-Rios, S. Torres-Rivera and A. V. \\ Méndez-Cruz ${ }^{2}$
}

\section{ABSTRACT}

Common guinea grass and new accessions of Panicum and Cenchrus grasses were evaluated in a cutting experiment in the semi-arid Lajas Valley over three periods: 126 days of cool weather and short days; 378 days; and nearly 2 years (672 days). The grasses were fertilized with $3,360 \mathrm{~kg} \cdot \mathrm{ha}^{-1}$ of a 15-15-10 fertilizer, divided in eight equal applications. The grasses were irrigated. The grasses were harvested every 42 days. In the 126-day period of short cool days, buffel 13084 and guinea 12917 were the highest dry forage yielders, with 11,371 and $11,061 \mathrm{~kg} \cdot \mathrm{ha}^{-1}$, respectively. In the 378 -day period, guinea \#13093, \#12917 and \#13092 produced statistically similar dry forage yields, which were higher than those of the other grasses. Among the Panicum grasses, guinea 13093 was the highest dry forage yielder $\left(45,574 \mathrm{~kg} \cdot \mathrm{K}^{-1}\right)$; among the Cenchrus grasses, buffel 13084 was the highest yielder $\left(35,247 \mathrm{~kg} \cdot \mathrm{K}^{-1}\right)$. In the 672 -day period, guinea $\# 13093, \# 13092$, and \#12917 outylelded var. common and all buffel grasses.

\section{INTRODUCTION}

In the southern part of Puerto Rico, where rainfall is limited during most of the year, high-yielding, drought-resistant grasses are needed for economic forage production. Species such as guineagrass (Panicum maximum Jacq.) and napiergrass (Pennisetum purpureum Schumach.), which are excellent for use as pastures, soilage and hay under conditions of adequate moisture, are seriously affected during prolonged drought. Buffelgrass (Cenchrus ciliaris L.) is also planted extensively by farmers on the southern coast, largely because of its resistance to drought.

A variety of buffelgrass, Tx-4464, was introduced in 1960 by Aurelio Sierra-Bracero of the Soil Conservation Service of the USDA. Since then, this cultivar has spread throughout the southern coastal area and now grows wild along roadsides and neglected areas. Another buffelgrass cultivar, known by the name American, was also introduced in the southern part of Puerto Rico. Both cultivars, which are similar in terms of morphology and agronomic behavior, are widely used for grazing and haying.

\footnotetext{
' Manuscript submitted to Editorial Board June 22, 1981.

'2Associate Agronomist, Corozal Substation, Agricultural Experiment Station, Mayagüe\% Campus, University of Puerto Rico; Research Geneticist Mayagüez Institute of Tropical Agriculture, AR, SEA, USDA, Mayagüez, P.R.; Research 'Technician, Corozal Substation, Agricultural Experiment Station; and Assistant Animal Husbandman, Lajas Substation, Agricultural Experiment Station, Mayagüez, Campus, Univ. P.R.
} 
Although guineagrass var, common has been studied extensively in Puerto Rico $(1,5,6,8)$, few reports are available concerning its yield potential in the southern coastal region. Sotomayor-Rios and VélezSantiago (6) showed that $P$. maximum, P.I. 3622, was significantly superior to guinea var. common in dry forage yield during a 2-year period at Lajas; and Boneta-García (2) showed that cultivar 'Salvador' was aiso superior to guinea var. common.

Vicente-Chandler et al. $(8,9)$ reported that in the humid region of Puerto Rico, short days and cool weather are the most important factors responsible for the relatively low forage yields from December to March. Sotomayor-Rios et al. (7) also found that high temperatures were associated with higher yields, and low temperatures with lower yields in a 2 year study conducted at Corozal with 19 forage grasses. No significant correlation was found between total rainfall and crude protein or dry forage yield of the 19 grasses.

It is worthwhile to search for grasses capable of sustaining high forage yields the year around with supplementary irrigation. These grasses would increase forage production in the southern region of Puerto Rico, where a large amount of flat land could be used more efficiently in livestock production.

This study was undertaken to evaluate the forage yield potentials of six buffelgrasses (Tx-4464, American and four new introductions) and four guineagrasses (common and three new introductions) during the period of short cool days from October to March, and also during a longer period of 672 days at the Lajas Experiment Substation. One of the guineagrasses under evaluation (12917) was reported to be an excellent: yielder during the cool season at the South Johnstone Research Station, Queensland, Australia (3).

\section{MATERIALS AND METHODS}

An experiment was performed at the Lajas Substation, located in a valley on the south coast of Puerto Rico, at an elevation of $100 \mathrm{~m}$. Average annual rainfall is approximately $1000 \mathrm{~mm}$, with a well defined dry season of variable length often lasting from December to June. Average air temperature is $26^{\circ} \mathrm{C}$. The soil is a Fraternidad clay (a Vertisol) with a $\mathrm{pH}$ of approximately 5.9 .

There were 10 treatments (grasses), 6 Cenchrus (buffel) and 4 Panicums (guinea) (table 1), with four replications, in a randomized complete block design. Individual plots were $2.4 \times 6.1 \mathrm{~m}$. Three-month-old seedlings were transplanted to the plots August 26, 1976, spaced $0.61 \mathrm{~m}$. The grasses were harvested 2 months later, and subsequently every 42 days for 16 consecutive cuttings. 
Nitrogen, $\mathrm{P}$ and $\mathrm{K}$ were applied as a 15-5-10 fertilizer at a rate of 3,360 $\mathrm{kg} \cdot \mathrm{ha}^{-1} \cdot \mathrm{yr}^{-1}$, divided into eight equal applications.

The grasses were cut by hand to 8 and $20 \mathrm{~cm}$ aboveground. The entire plot was harvested and the forage weighed, sampled, dried at $55^{\circ} \mathrm{C}$ in a forced air-oven and ground in a Wiley ${ }^{3}$ mill to pass through a $1 \mathrm{~mm}$ screen. Dry matter percentage was determined for all samples. For each treatment, $\mathbf{N}$ analyses of a composite sample of all harvests were made by replicates. Total $\mathrm{N}$ content was determined with a Technicon Auto Analyzer, and crude protein was calculated as $\mathrm{N} \times 6,25$. Calcium and $\mathrm{Mg}$ from each treatment were analyzed by flame photometry in a composite sample of the 16 harvests and four replicates after digestion with nitric and perchloric acids.

Table 1.-Identification of 10 forage grasses evaluated at Lajas, Puerto Rico

\begin{tabular}{|c|c|c|c|c|c|}
\hline \multirow{2}{*}{ Species } & \multicolumn{2}{|c|}{$\begin{array}{l}\text { Plant Lutroduction } \\
\text { Number }\end{array}$} & \multirow{2}{*}{$\begin{array}{c}\text { Other } \\
\text { number } \\
\text { or } \\
\text { cultivar }\end{array}$} & \multirow{2}{*}{$\begin{array}{l}\text { Original } \\
\text { source }\end{array}$} & \multirow{2}{*}{$\begin{array}{l}\text { Type of } \\
\text { cultivar }\end{array}$} \\
\hline & USDA PI ${ }^{1}$ & $\mathrm{PRPI}^{2}$ & & & \\
\hline Cenchrus ciliaris & 210693 & 13083 & & Rhod. & Tall \\
\hline do & 263509 & 13084 & & Ugan. & do \\
\hline do & 275102 & 13085 & & India & do \\
\hline do & 284837 & 13086 & & Austl. & do \\
\hline do & & & Texas 4464 & USA & Medium \\
\hline do & & & American & USA & do \\
\hline Pancium maximum & 284765 & 13092 & & Nigeria & do \\
\hline do & 291047 & 13093 & & Mexico & do \\
\hline do & & & Common & Africa & do \\
\hline do & 349676 & 12917 & CPI. $37910^{\circ}$ & Austl. & do \\
\hline
\end{tabular}

'United States Department of Agriculture plant introduction number.

"University of Puerto Rico Agricultural Experiment Station plant introduction number.

"Commonwealth plant introduction number from North Queensland.

During the first 378 days of experimentation (October 27, 1976 to November 9,1977 ) total rainfall was $911 \mathrm{~mm}, 57 \%$ of which occurred from August 1977 to November 1977. Rainfall during the remaining period (294 days) was $392 \mathrm{~mm}$. During the overall 672-day period, $711 \mathrm{~mm}$ supplemental irrigation was applied.

The data for yields of green forage (GF), dry forage (DF), crude protein (CP), and dry matter (DM) content were submitted to analysis of variance and Duncan's multiple range test.

\footnotetext{
"] Trade names in this publication are used only to provide specific information. Mention of a trade name does not constitute a warranty of equipment or materials by the Agricultural Experiment Station of the University of Puerto Rico or by the USDA, nor is this mention a statement of preference over other equipment or materials.
} 
The data were grouped for analysis as follows:

1. From October 27, 1976 to March 1, 1977, a period which covers the short days and cool weather at Lajas ( 3 harvests).

2. From October 27, 1976 to November 9, 1977, or about a 1 -year period (9 harvests).

3. From October 27, 1976 to August 31, 1978, a 672-day period (16 harvests).

\section{RESULTS AND DISCUSSIONS}

Table 2 shows the results obtained with the 10 grasses when harvested every 42 days during the period of short cool days at Lajas (October 27, 1976 to March 1, 1977). The highest yielders of green forage (GF) (guinea

TARLE 2.- Yield and dry matter content of 10 grasses harvested every 42 days during the short cool days at Lajas, Puerto Rico (October 27, 1976, to March 1, 1977)

\begin{tabular}{|c|c|c|c|c|c|}
\hline Species & $\begin{array}{c}\text { PRPI } \\
\text { number }\end{array}$ & $\begin{array}{c}\text { Green forage } \\
\text { yields }\end{array}$ & $\begin{array}{c}\text { Dry } \\
\text { matter } \\
\text { content }\end{array}$ & $\begin{array}{c}\text { Dry forage } \\
\text { yields }\end{array}$ & $\begin{array}{l}\text { Total crude } \\
\text { protein } \\
\text { yields }\end{array}$ \\
\hline & & $\mathrm{kg} . h a^{-1}$ & $\bar{y}$ & $\mathrm{~kg} \cdot h a^{-1}$ & kg. $h a^{-i}$ \\
\hline Cenchrus ciliaris & 13083 & $38,001 b^{\prime}$ & $24.59 \mathrm{bc}$ & $9,264 \mathrm{ab}$ & 746 cde \\
\hline do & 13084 & $42,849 \mathrm{ab}$ & $26,70 \mathrm{ab}$ & $11,371 \mathrm{a}$ & $990 \mathrm{a}$ \\
\hline do & 13085 & $36,034 \mathrm{~b}$ & $25.81 \mathrm{~b}$ & $9,335 \mathrm{ab}$ & 724 de \\
\hline do & 13086 & $42,940 \mathrm{ab}$ & $25.53 \mathrm{~b}$ & $10,742 \mathrm{a}$ & $959 \mathrm{ab}$ \\
\hline do $\mathrm{Tx}-4464$ & - & $24,881 \mathrm{c}$ & 28.24 a & $6,924 \mathrm{c}$ & $568 \mathrm{e}$ \\
\hline do American & 一 & $23,715 \mathrm{c}$ & 28.71 a & $6,831 \mathrm{c}$ & $583 \mathrm{e}$ \\
\hline Pancum maximum & 13092 & $43,665 \mathrm{ab}$ & $22.40 \mathrm{c}$ & $9,798 \mathrm{ab}$ & 917 abed \\
\hline do & 13093 & $48,473 \mathrm{a}$ & $20.76 \mathrm{~d}$ & $10,122 \mathrm{ab}$ & 901 abcd \\
\hline do Common & $\rightarrow$ & $37,332 \mathrm{~b}$ & $22.62 \mathrm{c}$ & $8,369 \mathrm{bc}$ & 788 bed \\
\hline do & 12917 & 48,383 a & $22.90 \mathrm{c}$ & 11,061 a & 928 abc \\
\hline
\end{tabular}

'Means followed by one or more letters in common do not differ significantly at the $5 \%$ probability level.

13093 and 12917$)$ produced an average of 385 and $384 \mathrm{~kg} \cdot \mathrm{ha}^{-1} \cdot$ day $^{-1}$, and were significantly superior to guinea var. common and buffels 13083 , 13085, Tx-4464 and American, but not to guinea 13092 and buffels 13086 and 13084. Buffel grasses, American and Tx-4464, had the highest dry matter (DM) contents, and were significantly superior to all remaining grasses except 13084 . The highest dry forage (DF) yielder, buffel 13084 , produced an average of $11,371 \mathrm{~kg} \cdot \mathrm{ha}^{-1}$ of DF during the 126 day-period or about $90 \mathrm{~kg} \cdot \mathrm{ha}^{-1} \cdot \mathrm{day}^{-1}$, which represents 36,64 and $66 \%$ more than guinea var. common, Tx-4464, and American, respectively. The two lowest DF yielders, Tx-4464 and American, were significantly inferior to the remaining grasses, except guinea var. common. The crude protein (CP) yield of buffel 13084 was the highest; while those of Tx-4464 and American were the lowest. Buffel 13084 produced $990 \mathrm{~kg} \cdot \mathrm{ha}^{-1}$ of CP 
during the 126-day period (about $7.86 \mathrm{~kg} \cdot \mathrm{ha}^{-1} \cdot \mathrm{day}^{-1}$ ) or 74,70 and $26 \%$ more than Tx-4464, American, and guinea var. common, respectively.

Table 3 shows the data accumulated over 378 days (9 harvests). The highest GF yielders were guinea 13093 and 12917 , which produced 204,661 and $182,464 \mathrm{~kg} \cdot \mathrm{ha}^{-1}$, respectively (about 541 and $483 \mathrm{~kg} \cdot \mathrm{ha}^{-1} \cdot \mathrm{day}^{-1}$ ), values significantly superior to the remaining grasses, except common and 13092. Guinea 13093 and 12917 proved to be good producers both during the short cool days and throughout the year. The two lowest yielders, Tx-4464 and American, had DM contents significantly superior to those of the remaining grasses except buffel 13084. In DF yield guinea 13093,12917 and 13092 were similar and significantly superior to the

ТАВLF. 3.- Yield and dry malter content of 10 forage grasses over a 378-day period at Lajas, Puerto Rico

\begin{tabular}{lccccc}
\hline Species & $\begin{array}{c}\text { PRPI } \\
\text { number }\end{array}$ & $\begin{array}{c}\text { Green forage } \\
\text { yields }\end{array}$ & $\begin{array}{c}\text { Dry matter } \\
\text { content }\end{array}$ & $\begin{array}{c}\text { Dry forage } \\
\text { yields }\end{array}$ & $\begin{array}{c}\text { Crude } \\
\text { protein } \\
\text { yields }\end{array}$ \\
\hline Cenchrus ciliaris & 13083 & $116,708 \mathrm{c}^{\mathrm{l}}$ & $27.13 \mathrm{c}$ & $30,865 \mathrm{c}$ & $2,458 \mathrm{de}$ \\
do & 13084 & $121,861 \mathrm{c}$ & $29.46 \mathrm{a}$ & $35,247 \mathrm{bc}$ & $2,930 \mathrm{~cd}$ \\
do & 13085 & $108,742 \mathrm{c}$ & $28.09 \mathrm{bc}$ & $29,791 \mathrm{c}$ & $2,277 \mathrm{ef}$ \\
do & 13086 & $124,979 \mathrm{c}$ & $26.94 \mathrm{c}$ & $32,635 \mathrm{c}$ & $2,767 \mathrm{cde}$ \\
do Tx-4464 & - & $78,601 \mathrm{~d}$ & $30.01 \mathrm{a}$ & $22,922 \mathrm{~d}$ & $1,881 \mathrm{f}$ \\
do American & - & $77,640 \mathrm{~d}$ & $29.23 \mathrm{a}$ & $22,093 \mathrm{~d}$ & $1,879 \mathrm{f}$ \\
Panicum maximum & 13092 & $171,655 \mathrm{~b}$ & $23.49 \mathrm{~d}$ & $40,267 \mathrm{ab}$ & $3,535 \mathrm{ab}$ \\
do & 13093 & $204,661 \mathrm{a}$ & $22.30 \mathrm{~d}$ & $45,574 \mathrm{a}$ & $3,863 \mathrm{a}$ \\
do Common & - & $168,217 \mathrm{~b}$ & $23.47 \mathrm{~d}$ & $39,318 \mathrm{~b}$ & $3,276 \mathrm{bc}$ \\
do & 12917 & $182,464 \mathrm{ab}$ & $24.60 \mathrm{~d}$ & $44,811 \mathrm{a}$ & $3,548 \mathrm{ab}$ \\
\hline
\end{tabular}

${ }^{1}$ Means followed by one or more letters in common do differ significantly at the $5 \%$ probability level.

remaining grasses except for the comparison 13092 vs. common. Guinea 13093 produced $45,574 \mathrm{~kg} \cdot \mathrm{ha}^{-1}$ (about $121 \mathrm{~kg} \cdot \mathrm{ha}^{-1} \cdot$ day $^{-1}$ ) or $16 \%$ more DF than common. The top buffel grass was 13084 , which produced 35,247 $\mathrm{kg} \cdot \mathrm{ha}^{-1}$ of DF (about $93 \mathrm{~kg} \cdot \mathrm{ha}^{-1} \cdot \mathrm{day}^{-1}$ ), similar to guinea var. common. Guinea 13093 , excelled in CP yield with $3,863 \mathrm{~kg} \cdot \mathrm{ha}^{-1}$, or about $10.22 \mathrm{~kg}$. $\mathrm{ha}^{-1} \cdot \mathrm{day}^{-1}$, and was superior to guinea var. common and to all of the buffel grasses.

Table 4 shows the performance of the 10 grasses during the 672 -day period (16 harvests). The GF, DF and CP yields of all four guinea grasses significantly exceeded those of the six buffel grasses. The lowest GF, DF and CP yields were those of Tx-4464 and American. The highest GF yielder, guinea 13093 , produced an average of $186,846 \mathrm{~kg} \cdot \mathrm{ha}^{-1} \cdot \mathrm{yr}^{-1}$ or $512 \mathrm{~kg} \cdot \mathrm{ha}^{-1} \cdot \mathrm{day}^{-1}$. This amount is about $20 \%$ more than that produced by variety common. The DF yields of the 10 grasses followed a trend 
TABIr 4.-Yield of 10 forage grasses cut every 42 days over a 672-day period at Lajas, Puerto Rico

\begin{tabular}{|c|c|c|c|c|c|c|c|c|}
\hline Species & $\begin{array}{l}\text { Treat- } \\
\text { ment } \\
\text { No. }\end{array}$ & $\begin{array}{c}\text { PRPI } \\
\text { No. }\end{array}$ & $\begin{array}{l}\text { Green } \\
\text { forage } \\
\text { yields }\end{array}$ & $\begin{array}{l}\text { Treatments } \\
\text { exceeded } \\
\text { at the } 5 \% \\
\text { level }\end{array}$ & $\begin{array}{l}\text { Dry } \\
\text { forage } \\
\text { yield }\end{array}$ & $\begin{array}{l}\text { Treatments } \\
\text { exceeded } \\
\text { at the } 5 \% \\
\text { level }\end{array}$ & $\begin{array}{l}\text { Crude } \\
\text { protein } \\
\text { yield }\end{array}$ & $\begin{array}{c}\text { Treatments } \\
\text { exceeded } \\
\text { at the } 5 \% \\
\text { level }\end{array}$ \\
\hline & & & $g-h a^{-1} \cdot y r r^{1-}$ & & $k g \cdot h a^{-1} \cdot y r r^{-1}$ & & $k g \cdot h a^{-1} \cdot y r^{-1}$ & \\
\hline Cenchrus ciliaris & 1 & 13083 & 97,790 & 5,6 & 25,631 & 6 & 2035 & . \\
\hline do & 2 & 13084 & 105,632 & 5,6 & 30,140 & $3,5,6$ & 2415 & $3,5,6$ \\
\hline do & 3 & 13085 & 89,481 & & 23,941 & & 1860 & \\
\hline do & 4 & - & 105,415 & 5,6 & 27,165 & 5,6 & 2252 & 5,6 \\
\hline do $\mathrm{Tx}-4464$ & 5 & - & 71,680 & & 20,205 & & 1662 & \\
\hline do American & 6 & & 68,250 & & 18,772 & & 1589 & \\
\hline Panicum maximum & 7 & 13092 & 156,843 & $1,2,3,4,5,6$ & 37,333 & $1,2,3,4,5,6$ & 3013 & $1,2,3,4,5,6$ \\
\hline do & 8 & 13093 & 186,846 & $1,2,3,4,5,6,7,9$ & 42,922 & $1,2,3,4,5,6,9$ & 3338 & $1,2,3,4,5,6$ \\
\hline do Common & 9 & - & 155,803 & $1,2,3,4,5,6$ & 36,689 & $1,2,3,4,5,6$ & 2960 & $1,2,3,4,5,6$ \\
\hline do & 10 & 12917 & 165,535 & $1,2,3,4,5,6$ & 40,797 & $1,2,3,4,5,6$ & 3062 & $1,2,3,4,5,6$ \\
\hline
\end{tabular}


similar to that of the GF yields. Guinea 13093, the highest DF yielder, produced $42,922 \mathrm{~kg} \cdot \mathrm{ha}^{-1} \cdot \mathrm{yr}^{-1}$ (about $118 \mathrm{~kg} \cdot \mathrm{ha}^{-1} \cdot$ day $^{-1}$ ) or $17 \%$ more than variety common. Among the buffels, the 13084 DF yield was significantly superior to those of $13085, \mathrm{Tx}-4464$, and American. The CP yields of the four guineas were similar and ranged from 3338 to $2960 \mathrm{~kg}$. $\mathrm{ha}^{-1} \cdot \mathrm{yr}^{-1}$ (from about 9.15 to $8.11 \mathrm{~kg} \cdot \mathrm{ha}^{-1}$. day). Among the buffel grasses, 13084 produced the highest CP yield, which was significantly different from those of $13085, T \times-4464$, and American.

Table 5 shows the average percentage composition of the 10 grasses during the 672-day period in terms of DM, CP, Ca and Mg. All the buffel grasses significantly exceeded the four guineas in DM content. Their respective ranges were from 29.1 to 26.4 , and from 24.9 to $22.9 \%$. In general, the protein content was very similar for the 10 grasses, and ranged from 8.46 to $7.50 \%$ in the dry forage. The average Ca content for the six buffel grasses was 0.24 , while that of the guinea was $0.57 \%$. This finding confirms previous studies which demonstrate a consistently higher $\mathrm{Ca}$ content in guineagrass than in other grasses (9). The average $\mathrm{Mg}$ content of guineagrass was $0.44 \%$, and the other grasses $0.29 \%$.

According to Paul and Lee (4), horses feeding on buffel grass alone can show symptoms of the big head disease (Osteodystrophia fibrosa). This condition is caused by an imbalance of $\mathrm{Ca}$ and $\mathrm{P}$ (less Ca than $\mathrm{P}$ ) or by a simple deficiency of $\mathrm{Ca}$ in the diet. Hay of buffel grass Tx-4464 is used to feed horses in the southern part of the island, although usually not as the sole ration. No cases of big head disease have been reported in Puerto Rico.

During the short days and cool weather, the best buffel grasses were as productive as guineagrass. On the other hand, when the grasses were evaluated during a 672 -day period, guineagrass was clearly superior to buffel in yield of dry forage and crude protein. Guinea 13093 was the most outstanding. Among the buffels, 13084 and 13086 were the superior producers of GF, DF and CP.

On the basis of these yield data, it would be possible to feed 7.88 or 8.85 steers of 273-kg liveweight ha ${ }^{-1}$. day ${ }^{-1}$ during the period of short cool days at Lajas with guinea 13093 or buffel 13084, respectively. During the 378-day and 672-day periods, the highest yielder, guinea 13093, produced enough forage to feed 11.82 and 11.53 such animals $\mathrm{ha}^{-1} \cdot$ day $^{-1}$, respectively.

\section{RESUMEN}

En la Subestación Experimental Agrícola de Lajas, localizada en los llanos costaneros del suroeste de Puerto Rico, se realizó un estudio con

\footnotetext{
${ }^{4}$ Assuming $20 \%$ waste and $50 \%$ digestibility, about $8.16 \mathrm{~kg}$ of dry forage would be required to feed a $273 \mathrm{~kg}$ steer gaining $0.45 \mathrm{~kg}$ daily (9).
} 
TABLE 5.-Dry matter, crude protein, Ca, and Mg contents of 10 forage grasses cut every 42 days over a 672-day period at Lajas, Puerto Rico

\begin{tabular}{|c|c|c|c|c|c|c|c|c|}
\hline \multirow{2}{*}{ Species } & & \multirow{2}{*}{$\begin{array}{l}\text { Puerto } \\
\text { Rjco } \\
\text { PI No. }\end{array}$} & \multirow{2}{*}{$\begin{array}{c}\text { Treat- } \\
\text { ment } \\
\text { No. }\end{array}$} & \multirow{2}{*}{$\begin{array}{c}\text { Dry } \\
\text { matter } \\
\text { content }\end{array}$} & \multirow{2}{*}{$\begin{array}{l}\text { Treatments } \\
\text { exceeded } \\
\text { at the } 5 \% \\
\text { level }\end{array}$} & \multirow{2}{*}{$\begin{array}{c}\text { Crude } \\
\text { protein } \\
\text { content }\end{array}$} & \multicolumn{2}{|c|}{$\begin{array}{l}\text { Mineral composition } \\
\text { (dry weight basis) }\end{array}$} \\
\hline & & & & & & & $\mathrm{Ca}$ & $\mathrm{Mg}$ \\
\hline & & & & $\%$ & & $\%$ & $\%$ & $\%$ \\
\hline Cenchrus ciliaris & & 13083 & 1 & 26.8 & $7,8,9,10$ & $7.93^{1}$ & 0.23 & 0.27 \\
\hline do & & 13084 & 2 & 29.1 & $1,3,4,7,8,9,10$ & 8.00 & 0.20 & 0.24 \\
\hline do & & 13085 & 3 & 27.2 & $7,8,9,10$ & 7.76 & 0.22 & 0.29 \\
\hline do & & 13086 & 4 & 26.4 & $7,8,9,10$ & 8.28 & 0.23 & 0.34 \\
\hline$T x-4464$ & & - & 5 & 28.9 & $1,3,4,7,8,9,10$ & 8.22 & 0.28 & 0.32 \\
\hline do American & & - & 6 & 28.2 & $1,3,4,7,8,9,10$ & 8.46 & 0.28 & 0.29 \\
\hline Panicum maximum & & 13092 & 7 & 23.9 & & 8.06 & 0.63 & 0.49 \\
\hline do & & 13093 & 8 & 22.9 & & 8.05 & 0.60 & 0.40 \\
\hline do Common & & - & 9 & 23.7 & & 8.07 & 0.55 & 0.34 \\
\hline do & & 12917 & 10 & 24.9 & & 7.50 & 0.49 & 0.52 \\
\hline Average for all grasses & & & & 26.2 & & 8.03 & 0,36 & 0.35 \\
\hline
\end{tabular}

'Average of 4 replicates. 
el propósito de comparar el potencial de producción de forraje verde (GF), forraje seco (DM), y proteína bruta (CP) de 10 cultivares de gramíneas de los géneros Panicum y Cenchrus por un período de 672 días consecutivos.

Los datos se analizaron por separado, incluyendo tres cosechas realizadas durante los días cortos del año (desde octubre 1976 al Iro. de marzo de 1977), por los primeros 378 días, y por los 672 dias de estudio.

Panicum maximum (PRPI 12917) y las Cenchrus ciliaris (PRPI 13084 y 13086) produjeron un 32,36 y $28 \%$ más de forraje seco DM que la Panicum maximum var. común durante los días cortos del año, respectivamente. Al considerar la producción media anual de DM de las 16 cosechas, las $P$. maximum (PRPI. 13093 y 12917) fueron las que más DM produjeron (42,922 y 40,797 kilogramos por hectárea y año, respectivamente). La yerba guinea var. común y la Buffel Texas 4464, las que más se usan en esta región, produjeron 36,689 y 20,205 kilogramos de DM por hectárea y año, respectivamente. La yerba Buffel (PRPI. 13084) fue la mejor productora de las cultivares Buffel, con 30,140 kilogramos de DM por hectárea y año. Las 10 cultivares siguieron un mismo patrón de producción de GF, DM, y CP cuando los datos se analizaron para los primeros 378 dias de estudio.

El contenido de CP fue bastante similar para ambos géneros, variando de $7.50 \%$ en la guinea (PRPI 12917) a $8.46 \%$ en la Buffel var. American. Los contenidos medios de Ca y $\mathrm{Mg}$ en las guinea fueron 0.57 y $0.44 \%$, mientras que en las Buffel fueron 0.24 y $0.29 \%$, respectivamente.

\section{LITERATURE CITED}

1. Abruña, F., Vicente-Chandler, J., and Pearson, R. S., 1964. Effects of liming on yields and composition of heavily fertilized grasses and on soil properties under humid tropical conditions, Proc. Soil Sci. Am. Soc. 28 (5): 657-61.

2. Boneta-García, E, 1954. Nuevas yerbas forrajeras para Puerto Rico, Publ. Misc. I2, Esta. Exp. Agríc. Univ, P.R.

3. Grof, B. and Harding, T. A. W., 1970. Dry matter yields and animal production of Guinea grass (Panicum maximum) on the humid tropical coast of North Queensland, Trop. Grassland $4(1): 85-95$.

4. Paul, C. J. and Lee, G. R., 1978. Buffel grass in Queensland, Queensl. Agric. J. 57-75, Jan; Feb.

5. Sotomayor-Rios, A., Acosta-Matienzo, A. and Vélez-Fortuño, J., I971. Yield comparison and plant character correlations on 16 Panicum accessions, J. Agric. Univ. P. R. 55 (2):174-83.

6. - and Vélez-Santiago, J., 1971. Yield comparison and plant character correlations on 16 Panicum accessions at the Lajas Valley, P. R., Agric. Exp. Stn. Annu. Rep. Hatch Proj. H-195.

7. - - Torres-Rivera, S. and Silva, S., 1976. Effect of three harvest intervals on 
CUTTING MANAGEMENT: PERFORMANCE, OF FORAGE GRASSES 277

yield and composition of nineteen forage grasses in the humid mountain region of Puerto Rico, J. Agric. Univ. P. R. 60 (3):294-309.

8. Vicente-Chandler, J, and FigarelIa, J., 1958. Growth characteristics of Guineagrass on the semiarid south coast. J. Agric. Univ. P. R. 42 (5):151-60.

9. - - Abruña, F., Caro-Costa, R., Figarella, J., Silva, S. and Pearson, R. W., 1974. Intensive grassland management in the humid tropics of Puerto Rico, Univ. P. R. Agric. Exp. Stn. Bull, 233. 